\title{
Clío y la antropología. Pensando con la historia en el presente de Ávila y de Évora
}

\author{
MARÍA CÁTEDRA \\ Universidad Complutense de Madrid
}

\begin{abstract}
RESUMEN
Tras un largo periodo dominado por el funcionalismo y el estructuralismo, desde los años ochenta la antropología viene beneficiándose de un acercamiento a la historia, comparable al interés cada vez mayor de los historiadores por la antropología. La autora ha vivido de cerca esta transformación, que ha tenido lugar al tiempo de su desenvolvimiento profesional y que ha quedado registrada en sus publicaciones. El estudio de la construcción simbólica de ciudades cargadas de historia, como Ávila y Évora, le facilitó el cambio. Pero no se trata de una mezcla fácil de las dos disciplinas y enfoques, como si cada uno hubiera encontrado al final la media naranja que le faltaba. Aunque el antropólogo debe estudiar la historia, la lectura histórica clásica -el análisis de documentos del pasado- no le será suficiente. Debe estudiar la historia como fuente y organización de significados en el presente. Si se fija bien, el antropólogo del presente descubrirá que sus informantes no sólo son herederos de una historia, sino que también piensan con ella.
\end{abstract}

Palabras clave: Historia conjetural, Sincronía, Diacronía, Vaqueiros de alzada, Ávila, Évora, Virgen de Sonsoles, Antropología histórica.

\section{SUMMARY}

After a long period dominated by functionalism and structuralism, since the 1980's anthropology has benefited from its closeness to history, comparable with the increasing interest by historians in anthropology. The author has lived through this transformation, which has taken place at the time of her own development as an anthropologist and can be perceived in her publications. Her research on the symbolic construction of historyladen cities such as Avila and Evora facilitated this development. However, it is not a matter of easily complementing one discipline and approach with the other, as though each would have found at last its better half. Although anthropologists must study history, the classical approach of history - the analysis of documents from the past- will not be enough for them. Anthropologists must study history as source and organization of meanings in the present. Should he look closely, the anthropologist of the present will realize that his informants are not only heirs to history, but think with it too.

Key words: Speculative history, Synchrony, Diachrony, Asturian Herdsmen, Avila, Evora, Lady of Sonsoles, Historical Anthropology.

RDTP, LIX, 1 (2004): 203-231 


\section{UNA DIFÍCIL UNIÓN DE HECHO}

Si se me permite el símil sentimental, las relaciones entre Historia y Antropología son desde la década de 1980 las de una pareja con sus más y sus menos, como todas las parejas, pero con convergencia de intereses, métodos y préstamos recíprocos. En muchos aspectos ambas disciplinas son coincidentes, si bien hay también algunas cuestiones que las hacen distintas. Pero esta "unión de hecho" entre dos disciplinas convergentes aunque diferentes no siempre turo lugar; muy al contrario, hasta mediados del siglo XX se consideraron dos campos perfectamente separados. Voy a intentar señalar algunos hitos de este proceso desde la perspectiva antropológica ${ }^{1}$.

En el pasado, la antropología ha tenido épocas de atención a la historia y épocas a-históricas o anti-históricas. Con todos los defectos que les hicieron merecedores de la etiqueta de practicantes de la "historia conjetural", los evolucionistas y difusionistas se encuadran en el primer grupo de los amantes de la historia (una historia, como se ha destacado repetidamente, muy sui generis) junto con Franz Boas y su escuela. Más tarde, el estructuralfuncionalista A. R. Radcliffe-Brown, al intentar excluir la "historia conjetural", excluye toda la historia; así se da la paradoja de que, durante un tiempo, los relatos etnográficos esconden incluso la historia más reciente de los pueblos que se estudian. Me refiero concretamente al contacto colonial, que en muchas monografías quedó reducido a un pequeño apartado llamado "cambio social" frente a la "auténtica cultura tradicional". Algunos antropólogos nostálgicos incluso se erigieron como defensores de la pureza prístina, como Edward S. Curtis, quien parece intentó convencer a los indios americanos de que adoptaran su traje "tradicional", lleno de plumas al estilo Hollywood.

Aun cuando se abogaba por la historia, ésta aparecía bajo la rúbrica de "etnohistoria", un término muy poco inocente que ha escondido una significación hoy caduca y en entredicho. Creado en 1909 por Clark Wissler en relación con las tribus de los indios americanos, el vocablo hacía referencia al estudio de grupos étnicos a través de documentos que, normalmente, habían sido producidos por no nativós. En los años cincuenta florecieron conferencias y sociedades dedicadas al estudio de la etnohistoria de los pueblos que el antropólogo estudiaba de una manera, por cierto, un tanto aislada. En la actualidad, el término todavía tiene un referente tribal o pagano y denota

\footnotetext{
${ }^{1}$ Este ensayo ha sido cuidadosamente leído y revisado por mi colega y amigo el historiador Serafín de Tapia, quien ha mejorado el texto y matizado algunas de mis más osadas afirmaciones (aunque otras, me temo, aún persisten). Nuestra relación intelectual es, para mí, el mejor ejemplo de coláboración e interdisciplinariedad entre ambas disciplinas.
} 
exclusión: los grupos tribales o minoritarios tienen "etnohistoria", mientras que los occidentales simplemente "historia" (Krech 1996).

Desde las dos perspectivas - la histórica y la antropológica-, tanto E. E. Evans-Pritchard como Fernand Braudel plantearon la necesidad de una comunicación mutua entre ambas disciplinas. En los años sesenta, William Sturtervant (1966) destacó una diferencia clave entre ambas. Por un lado, los historiadores reconocen que la historiografía conlleva la selección de algunos hechos frente a otros y la atribución de significado o significación a los hechos seleccionados; no obstante, todavía hay un énfasis en los "sucesos únicos". Los antropólogos, por su parte, están demasiado apegados a las clasificaciones, las tipologías y las generalizaciones. Sturtevant indica que no se puede distinguir entre historia empírica o especulativa: toda historiografía es especulativa hasta cierto punto y toda evidencia histórica es hasta cierto punto empírica. Plantea, pues, la necesidad de la evaluación crítica de las fuentes. Y también que no hay una historiografía definitiva: "cada generación escribe su propia historia". La historiografía es un arte literario en el sentido de que la selección de temas interesantes y la evidencia que sustenta la descripción y el análisis depende de la imaginación del historiador, las modas del momento en la historia académica y el ambiente cultural que le rodea.

Esta posición crítica contrasta con lo que ha estado pasando en el ambiente antropológico. En la década de 1960, de la mano del neoevolucionismo y la antropología marxista, se trataba de situar las culturas en su contexto económico y político pero no plenamente histórico. Para los antropólogos de entonces, el estudio de la historia se basaba en documentos de archivo frente a la historia oral, se fijaba en los que escribieron los documentos y no en los que sólo aparecían marginalmente en ellos y se privilegiaba a los documentos oficiales sobre otros más personales o casuales que podrían ofrecer otra perspectiva de las relaciones coloniales. Después, sin embargo, empezarán a aparecer estudios históricos sobre los campesinos, la clase obrera o las mujeres, tres sectores hasta entonces poco estudiados. Y se planteará el problema fundamental de que el objeto de estudio tiene una íntima conexión con la manera como se estudia este "dbjeto.

A este respecto es fundamental la, aportación de Berhard Cohn, quien desde los años sesenta produce diversos artículos que serán nuevamente editados, ya en los ochenta, en el texto An Anthropologist Among the Historians and Other Essays (Cohn 1990)! De una forma irónica y divertida, como si se tratara de un trabajo de campo entre la tribu de los historiadores, este antropólogo va desgranando las diferencias y estereotipos mutuos de ambas "tribus". Una diferencia clave para él es que la investigación en historia se basa en la localización de los datos; mientras que el antropólogo los crea él mismo. El material (y no tanto las buenas ideas) sería, pues, lo fun- 
damental para el historiador, mientras que el antropólogo empieza con un problema y debe decidir qué tipo de material necesita para investigarlo. En otras palabras, un estudiante de historia piensa "qué material disponible me permite hacer una tesis" en vez de "qué problema me interesa" (Cohn 1990: $5-8,11)$.

Ambos grupos tienen estereotipos mutuos falsos: los historiadores creen a menudo que los antropólogos están excesivamente atados a su metodología y modelos analíticos y, en cambio, ponen poca atención a los hechos en sus contextos. Los antropólogos piensan que los historiadores se aferran a los hechos, pero no tienen modelos analíticos ${ }^{2}$. Son estereotipos porque el antropólogo no suele tener ningún modelo antes de realizar su trabajo de campo; construye el modelo al juntar los datos que ha recogido y sitúa este modelo en una teoría general de la sociedad. El historiador comienza con un modelo de lo que son las culturas o sociedades y cómo funcionan y después sitúa los hechos en este modelo; termina su investigación presentando sus datos, pero sin discusión del modelo que está usando. El antropólogo trabaja con la fe de que lo particular puede ser colocado dentro de un sistema que lo explique. El historiador a menudo desprecia la significación de estructuras, culturas y relaciones, pensando que son el resultado de sucesos caprichosos. Su sistema consiste en sucesos que pueden ser situados en un orden cronológico (esto es, en definitiva, la historia). El antropólogo debe crear un nuevo sistema de ordenar sus observaciones con cada pieza de investigación; empieza trabajando con un problema que coloca en un marco teórico. Cuando el historiador habla de un problema, es puramente descriptivo (el estudio de un periodo particular, un suceso, una biografía, la obtención de datos inéditos). Por ello, según Cohn (1990: 6-8), los historiadores tienden a no solapar estudios, mientras que esto es más frecuente entre antropólogos, que tratan con la posibilidad de explicaciones múltiples.

Un historiador es regular en sus hábitos de trabajo: fundamentalmente trabaja en archivos y también con material impreso. El antropólogo trabaja

\footnotetext{
${ }^{2}$ Todavía de vez en cuando aparecen algunos de estos estereotipos por ambas partes. Un ejemplo reciente desde la historia es el de Jon Mitchel (1997). Según él, la antropología y la historia representan proyectos distintos, con diferentes metodologías e identidades opuestas. En la antropología hay tres falacias: el presentismo (se asume el valor del estudio sincrónico), el centrismo (exploración de lo local sólo en términos de lo nacional e internacional) y la abstracción (tendencia a explicar procesos socio-culturales sólo en términos de asunciones teóricas). Para este autor, hay que hacer más investigación orientada a la práctica, no sólo a la teoría. Este caso contrasta con el de historiadores sensibles a la antropología, como por ejemplo Tapia (1991, 1999) y James Amelang (1986), y con el de antropólogos con sensibilidad por la historia como Susan Tax Freeman (1979) y William Christian (1997), quienes han trabajado sobre temas ibéricos.
} 
sin horario fijo, atento a sus informantes y sucesos de la sociedad en cuestión; su material es entonces potencialmente infinito, puesto que lo crea él mismo. Por el contrario, el material del historiador tiene un carácter finito: puede ser el material de una biblioteca o archivo o cada documento conocido de un lugar particular en un tiempo particular; puede hacer un trabajo exhaustivo, porque sobre un determinado asunto sólo sobrevive un número limitado de documentos. En cierta manera es un trabajo estándar, en el sentido de que el investigador recorre las fuentes y piensa que teóricamente un trabajo se puede terminar. No es éste el caso del antropólogo, que tiene pilas de material que no siempre utiliza en sus pequeños manuscritos y publicaciones. La antropología no es una disciplina acumulativa como lo es la historia. Los avances intelectuales se producen al hacer nuevas conexiones entre los datos que crea el propio antropólogo observando las sociedades (Cohn ibid: 9-10).

El antropólogo ha convertido su método en algo sagrado: el trabajo de campo. El hecho central que ha descubierto la antropología es que la gente tiene vidas llenas de sentido y esos significados sólo pueden ser descubiertos en el contexto de esas vidas. En el pasado, la práctica de la investigación histórica estuvo dominada por una teoría positivista simplista: hay hechos históricos que se pueden datar, que se verifican a través de la comparación de fuentes para descubrir lo que realmente pasó. La historia fue durante tiempo la búsqueda del error, error de hechos o de interpretaciones. Pero la búsqueda del error tiene que ver con la noción de "autenticidad": había que ser revisionista, depurar (Cohn ibid: 34 ).

Junto al método, está el objeto de estudio. El antropólogo —se diceestudia cosas insignificantes que sitúa en términos generales; el historiador estudia un tema importante y se contenta con ello. Imperceptiblemente se ha producido una implícita división del trabajo, un estereotipo por el cual el historiador tradicional ha estudiado a los poderosos y los problemas centrales de las sociedades centrales, mientras que el antropólogo ha dedicado su atención a sociedades fuera del tiempo y de la historia, a los humildes, a los márgenes de las sociedades.

$\mathrm{Y}$, sin embargo, historiadores y antropólogos tienen un mismo objetivo: el estudio del otro en el tiempo y en el espacio respectivamente, un interés en el texto y el contexto y en explicar el significado de las acciones de la gente. En ambos casos se trata de realizar un acto de traducción. Los dos tratan de comprender y explicar, dan sus resultados en forma literaria y han tratado sin éxito de desarrollar marcos de referencia conceptuales para la comparación y el cambio social. Y aquí es donde se produce la conjunción entre historia y antropología: según Cohn (ibid: 42), la historia puede llegar a ser más histórica al hacerse antropológica, como la antropología puede lle- 
gar a ser más antropológica al devenir más histórica. Al utilizar la antropología una metodología sincrónica, reifica y objetiviza la sociedad estudiada. Al introducir la historia, descubre que toda la cultura es construida. Y puesto que la cultura es construida y constituida, puede ser transformada. El proceso de construcción de las culturas se puede estudiar a través de las representaciones más que en la estructura u organización social. En el colonialismo, lo que se produce es un choque entre diferentes formas de representación del mundo y de uno mismo. El estudio de un sitio particular en un período concreto es sobre la construcción de categorías y procesos, no estrictamente sobre tiempo y espacio.

El archivo y el campo contrastan como dos modos diferentes de comprensión que cada uno representa. El texto y el contexto se crean simultáneamente. El historiador necesita de la experiencia directa de otra cultura, comprender que hay otros sistemas posibles, lógicas culturales, tanta racionalidad como en la propia cultura, otros lenguajes. Necesita pensar que lo que parece trivial puede ser significativo para entender cómo se estructuran y construyen otras culturas. Los archivos son artefactos culturales que incluyen el pasado y el presente: los textos tienen que ser leídos no sólo como hechos o indicaciones sino como significaciones. El pasado existe no sólo en los documentos del pasado, sino también en el presente: sobrevive en los edificios, objetos y paisajes de hoy día; su observación ayuda a construir el contexto. El campo y el archivo son complementarios.

Ya Marshall Sahlins (1981, 1983, 1985) planteó que la historia puede ser diferente en diferentes sociedades y que no tiene por qué ser la antítesis de la estructura, sino integrarse mutuamente. En el caso de la muerte del Capitán Cook en Hawaii en 1779, los sucesos recapitularon la estructura mítica de las sociedades del Pacífico. La cultura es precisamente la organización de la situación actual en términos del pasado; Sahlins ha mostrado la interrelación dinámica de mito, ritual e historia. Sin embargo, también se le ha acusado de no considerar el cambio interno y real en estas sociedades (su proletarización, por ejemplo; o el cambio al cristianismo); algo que, por cierto, sí han hecho Jean y John Comaroff (Comaroff 1985; Comaroff y Comaroff 1991) tratando de ver a los pueblos indígenas como agentes activos en sus historias, analizando la poética de la historia opresiva y las sutilidades de la consciencia colectiva culturalmente codificada. Hoy se considera que la etnohistoria es un método, no una disciplina, y no precisa de la etiqueta "etno". Los problemas de investigación actuales son los estilos de pensamiento histórico de los indígenas, sus conceptos de tiempo, las invenciones de la cultura o los modos culturales de conocer o hacer historia. Se ha pasado, en otras palabras, de la etnohistoria a la historización de la antropología.

La utilización de fuentes poco convencionales, el empleo de la historia 
oral y lecturas críticas e imaginativas de documentos históricos clásicos han permitido llegar a los márgenes de la documentación histórica y recuperar a los que no tienen voz. Y también han permitido el poder contemplar con una nueva luz a los poderosos y a los humildes. De aquí parten los primeros contactos y relaciones de ambas disciplinas. La influencia de Victor Turner o Clifford Geertz en el interés de algunos pioneros historiadores por la cultura, el drama o el ritual (como N. Z. Davis, G. Dening o R. Darton) ha sido ampliamente reconocida. El estudio de la formación y desarrollo social de clases, grupos y relaciones proviene de la anterior tradición marxista estructuralista. $\mathrm{Y}$ en otros casos se ha tratado de conjugar la investigación de archivo con la investigación etnográfica (como han mostrado el propio Bernard Cohn o Renato Rosaldo). En los últimos tiempos, la historia desde abajo hacia arriba se ha dedicado al estudio de las masas, los explotados, los grupos marginados..., grupos que dejan poca huella con los materiales clásicos. Por ello estos investigadores o han realizado una lectura diferente de la documentación de archivo o han desarrollado nuevas fuentes: el uso de tradiciones orales, diferentes clases de materiales, el estudio de rituales, folklore, canciones, en definitiva la construcción de la cultura, de sistemas de conceptos, significados y creencias que se incorporan en símbolos.

Por último, la más reciente producción sobre invención de tradiciones apunta a un tema muy crucial: la multiplicidad de construcciones del pasado y los modos de construirlo. Hoy se considera que la historia oral no es una mera recolección de información sobre sucesos que no podrían ser documentados de otra manera (la genealogía ha sido un ejemplo clásico), sino que muestra fundamentalmente la percepción del pasado de un grupo (es decir, la estructura de la narrativa, la posición y motivos de los narradores o el tema del poder en la elaboración de la memoria). Estos estilos y géneros de historicidad son un tema actual de investigación; por ejemplo en relación con el colonialismo, que hoy los antropólogos estudian desde la perspectiva del colonizado y del colonizador, intentando plasmar la práctica cotidiana de opresión y resistencia. Y no sólo se ha estudiado el proceso colonial desde ambos lados, sino que se ha intentado trazar (por George Stocking, entre otros) la formación del conocimiento antropológico en conexión con la práctica del colonialismo.

Y si hablamos de diversas historicidades, Jonathan Friedman (1992) ha analizado las relaciones entre la identidad y las políticas de la construcción histórica. De acuerdo con este autor, el hacer historia es un modo de producir identidad, puesto que genera una relación entre lo que supuestamente ocurrió en el pasado y el estado actual de las cosas. La construcción de historia es la construcción de un universo significativo de sucesos y narrativas sobre un individuo o una colectividad. Toda historia, incluyendo la historiografía 
moderna, es mitología. La construcción del pasado es un acto de auto-identificación y debe ser interpretado en su autenticidad; es decir, en términos de su relación existencial entre sujetos y la constitución de un mundo significativo. La Grecia clásica es un aspecto crucial de la identidad emergente de Europa (Friedman 1992: 837-841, 855-856). Historia y antropología son formas de conocimiento, propias de la cultura europea. La teoría nativa del tiempo se transformó en cronología, con la idea de que el tiempo puede ser medido objetivamente y computado en periodos donde tienen lugar sucesos. Los europeos creen que el mundo tiene un origen que se puede datar. Así se distinguió durante mucho tiempo entre historia verdadera y mitos o fábulas. Al inventar la cronología, los europeos construyeron un mundo real fuera del pasado natural y englobante. Para los europeos todo tiene una historia $\mathrm{y}$, descubriéndola, la explicamos. La historia de los europeos ha sido parte de su control del espacio -como ha indicado François Furet (en Cohn 1990: 51) — y de la definición y creación de fronteras entre Estados.

De los Sincrónicos Vaqueiros a las diacrónicas Ávila y Évora. Breve MEMORIA DE UN QUEHACER ANTROPOLÓGICO

Nadie puede negar que ha habido un vuelco importante y significativo en antropología entre la década de los setenta —empeñados como estábamos en análisis formales, componenciales y estructuras cognitivas- y la de los ochenta, en que los antropólogos se enamoraron de la historia, siguiendo con el símil afectivo. En mi propia experiencia viví este cambio entre mi formación en la Universidad de Pensilvania en los años setenta (y especialmente con un director de tesis como Ward Goodenough) y mi docencia durante un curso académico en la de Chicago veinte años después. Bien es verdad que ambas universidades tienen una trayectoria diferente y que en la de Chicago no sólo trabajan Sahlins, los Comaroff o Stocking, sino también uno de los pioneros de la antropología histórica, el ya citado Bernard Cohn ${ }^{3}$. Como se me ha pedido que reflexione sobre mi propio desempeño, lo voy a hacer a continuación dentro de este contexto que acabo de perfilar.

Ya hace más de treinta años que comencé mi trabajo sobre los vaqueiros de alzada asturianos, que dio como resultado varias publicaciones (Cátedra y Sanmartín 1979; Cátedra 1988, 1989, 1992). El proyecto fue básicamente una investigación a-histórica y reflejó una época, como no podía ser menos. En

\footnotetext{
${ }^{3}$ No me extraña que el organizador del curso que dio origen al presente volumen, Juan J. Villarías Robles, haya seleccionado este tema de la antropología y la historia, teniendo en cuenta su formación en la Universidad de Chicago. Le agradezco su amable invitación a reflexionar sobre este fascinante asunto.
} 
torno a los vaqueiros se había desarrollado una "historia conjetural" basada en orígenes y supervivencias que me dediqué a deconstruir, como diríamos ahora. Mi incursión en el pasado fue un intento de probar la falacia de una "raza maldita" y de rechazar los múltiples orígenes que se le suponía. En los comentarios de los vaqueiros que aparecían en los libros que escribí, aparecen continuas referencias al pasado; pero es un pasado en cierto modo mítico (o así lo consideré yo) que comienza con "los de antes.." o "en los tiempos antiguos...". Más propiamente, mi trabajo (y especialmente el estudio de la muerte) fue en realidad el estudio de una cosmología, una cosmología fuera del tiempo. William Christian, quien tradujo ese libro al inglés (Cátedra 1992), me hizo comprender la necesidad de investigar históricamente las cosmologías europeas. También Enrique Luque, en una sensible crítica (1988), señalaba este aspecto.

Aparte de los valiosos testimonios de historia oral preservados en las numerosas citas de los vaqueiros, mi incursión consciente en territorio histórico clásico se redujo al vaciado de los Libros de Difuntos de una de las parroquias donde trabajé. Este material (en total 1266 partidas), que comienza en 1768 y termina en 1936, resultó ser muy interesante. En las partidas de defunción aparecía información sobre formas de vida, trashumancia, marginación y muchos otros datos para comprender el pasado de los vaqueiros, pero especialmente información sobre tres materias: las enfermedades de que morían los parroquianos, las mandas materiales a los que quedaban y las ofrendas a la divinidad. Las partidas fueron escritas por párrocos que mostraban diferentes grados de interés por estas materias a lo largo de los años. Hubo modas en los tres aspectos, pero particularmente en enfermedades y devociones, así como "especialistas" en uno u otro tema entre los que escribían. Obviamente, las ofrendas a la divinidad beneficiaban a los párrocos y existía una cierta competencia con las ofrendas o mandas hacia los vivos. También había en algunos casos una especie de censura (por ejemplo, la de los párrocos que ignoraban o disfrazaban de "sobrinos" a los hijos ilegítimos) y en general un estilo eclesiástico de escritura. A través de las partidas, especialmente en aquellos casos de curas que habían permanecido muchos años en la comunidad, se dibujaba un panorama aceptable de la personalidad e intereses del autor de las partidas.

Pero es éste un material que apenas he analizado. Escribí un artículo, traducido y presentado en inglés para un congreso internacional que se realizó en Braga (Portugal) en 1986; ironías del destino, perdí el original en castellano y el artículo acabó publicado años después en una revista asturiana, mediante traducción directa del inglés al bable o asturiano. Este azaroso final tiene que ver, sin duda, con la característica del material en cuestión y mi consideración del mismo. Si tenía que elegir entre la información formal 
y estereotipada de un conjunto de eclesiásticos y la que me proporcionaban los propios vaqueiros con espontaneidad, cercanía y mucho encanto, la elección para mí, en ese momento, era simple: los documentos de archivo y los curas que los habían escrito eran siempre intermediarios frente a la inmediatez de mis datos con mis informantes, sólo tamizados por el magnetofón que usaba. Evidentemente me olvidaba de mí misma, que no era ni transparente ni ajena a aquel escenario. Y hoy me planteo que no tendría por qué haber tenido que elegir entre ambos tipos de material, sino complementarlos. Pese a mi olvido de la historia, se da la paradoja de que actualmente mis propios datos e interpretación forman parte de la historia reciente de los vaqueiros, historia al fin y al cabo que pertenece incluso a otro siglo, y mis materiales tendrán que ser evaluados igualmente en su contexto intelectual y humano.

El cambio de lugar de investigación a Ávila ha significado una transformación radical en mi relación con la historia. Si entre un pequeño grupo de pastores se puede ignorar la historia, no puede hacerse lo mismo en una ciudad del tipo de la que decidí estudiar. En una ciudad hay muy distintos tipos de construcciones; las ciudades están hechas con piedras, pero también con jerarquías, con ideas, con símbolos y con memoria. Mi interés inicial -cómo se construye simbólicamente una ciudad - me llevó a considerar su mitología. La mitología encierra una definición cultural de una comunidad, permite la especificación local, el escrutinio de su historia, muestra sus aspiraciones y deseos, es la forma de presentarse al exterior. Una ciudad se da a conocer por la ostentación de sus emblemas y mitologías. Como el conocimiento de otras culturas y tiempos debe partir de la definición de las propias culturas, la representación de la ciudad en una cultura urbana es clave en ello; o, mejor, lo son las representaciones de las ciudades, pues estas representaciones pueden provenir de diferentes perspectivas: desde dentro, desde fuera, desde distintas clases sociales, desde intereses contrapuestos, etc. Varios de los lemas de Ávila (la ciudad "de las murallas", "de los santos", "de los caballeros" y "la del rey") han sido estudiados por mí misma o por el equipo que formé en su día; son una guía local de aspectos significativos.

Los mitos de las ciudades han sido en general poco estudiados. La fundación, o fundaciones, de la ciudad constituyen referencias cronológicas, apuntan a los fundamentos de la historia de la ciudad, a los hitos de su construcción. La mitología de las ciudades españolas, que se forja fundamentalmente en el siglo XVI, es posteriormente despreciada y abandonada por los historiadores del XIX tras la revisión y crítica a la que se la somete: tarea necesaria desde el talante positivista de la época, pero que deja poco a cambio. Los mitos son parte de un corpus general de comentario sobre la naturaleza humana (al igual que el cuento, la ciencia social, la religión o la filosofía), un instrumento humano para entenderse, entender el mundo que nos rodea y 
enfrentarse a lo desconocido. Son sistemas semánticos estructurados de una cultura y, en definitiva, ofrecen información sobre los valores de una época y sobre la sociedad que los mantiene. En este caso, los mitos muestran cuanto de construcción simbólica tienen las ciudades.

He analizado las imágenes mitológicas de la ciudad de Ávila a través de la historia de su primer obispo (Cátedra 1997). Este ángulo me pareció interesante para abarcar la fundamental complejidad diacrónica de la ciudad, la continuidad con el presente y la creación de su imagen frente al exterior, la tan conocida de "ciudad de santos". En Un santo para una ciudad, el título del libro en cuestión, exploro la mitología de Ávila a través del patrón de la ciudad inventado en el siglo XVI, pero también las fuerzas sociales que lo crearon y mantuvieron durante el siglo más crucial de la historia de Ávila. Exploro a la vez el contexto local y el contexto nacional, el juego con el pasado y el presente a través del culto actual, la acción de los poderosos y de los humildes, su escrutinio de la mitología y de la historia; lo cual es ideología, pero también práctica social. Es probable que algunos historiadores tradicionales no estén de acuerdo con este enfoque y con el material en que se basa, bastante poco ortodoxo: etnografía de la ciudad, vidas de santos y fuentes secundarias. Ni rastro, o muy poco, de documentos de archivo: un material tan mitificado por el historiador clásico. Es también probable que éste no esté de acuerdo con mi interpretación: las interpretaciones no suelen ser bien recibidas por quien está tan apegado a la descripción, como si la descripción no fuera también interpretación... Aunque hay excepciones.

Otro tema mitológico fundamental en Ávila ha sido el de la construcción de las murallas medievales. Sobre él he trabajado conjuntamente con el historiador Serafín de Tapia (Cátedra y Tapia 1997). Hemos intentado ofrecer las dos perspectivas de un mismo objeto, la mitológica y la histórica, a través de tres escenarios: la construcción física y mental de las murallas, la guerra con los otros (la desigualdad entre los sexos y los grupos étnicos) y la guerra con uno mismo (la estratificación social). Ha sido un primer intento de unir ambas perspectivas, de hacer confluir la información procedente de los significados simbólicos con la de los históricos. El trabajo se enmarca en un proyecto más amplio sobre las murallas abulenses, donde también tienen su voz, por una parte, los poetas, viajeros y escritores de distintas épocas y, por otra, sus estudiosos, aparte de sus usuarios, las gentes que con ellas conviven en la actualidad.

El lector se habrá percatado de mi facilidad para moverme por la historia de Ávila, pasando de la época medieval al siglo xvı o al xx con cierta alegría. Éste ha sido también un motivo de tensión con historiadores convencionales, quienes normalmente se refugian en su conocido y concreto periodo de especialización. Pero esta soltura al traspasar límites no sólo tiene que ver 
con el tiempo sino también con el espacio: hace poco he realizado trabajo de campo en otra ciudad: Évora, en Portugal. Ya antes de vivir en ella, inicié el estudio de la mitología eborense comparándola con la de Ávila (Cátedra 1999, 2001a). Recorrer ciudades históricas como Ávila o Évora supone sumergirse en el tiempo, reconocer retazos de historia a través de calles y monumentos, rastrear otras culturas plasmadas en piedra y estructura, aunque también toparse con jirones de su mitología: en el caso de Évora, con el templo romano de Diana (que nunca estuvo dedicado a Diana), con la Praça do Giraldo sem Pavor, el legendario conquistador de la ciudad, con la Capela de S. Manços (San Mancio), sủ presunto primer obispo, o con la Igreja de S. Vicente, también presunto hijo de la ciudad. En Ávila, el viajero puede leer los nombres de santos, políticos, guerreros y escritores rodeando la columna que corona Santa Teresa, patrona de la ciudad (y una de sus más mitificadas figuras) en medio del Mercado Grande. En esta céntrica plaza hay una segunda estatua de la misma santa (lo que delata su importancia), al pie de sus célebres murallas y cerca de la calle de San Segundo, el patrón de la ciudad, un santo que nunca existió. El monumento está dedicado a las Grandezas de Ávila y su colección de nombres pretende abarcar la historia de la ciudad o al menos sus más importantes hitos y símbolos en el momento de su erección, a finales del siglo XIX. Hoy día algunos de estos símbolos han quedado obsoletos y otros han cambiado de significado. La propia Santa, por ejemplo, ya no es la "santa de la raza", como se la denominaba en época franquista, porque -ironías del destino- tenía más de una "raza": hoy se sabe que tuvo antepasados judíos. Pero, además, tal como ha mostrado Eduardo Cabezas (2000), sus "antigüedades y grandezas" no son tales, pese al pomposo título que a sí misma se ha dado de "la ciudad de los caballeros", ya que sus "caballeros" ni son antiguos ni "grandes".

Los mitos de Évora se fabrican fundamentalmente entre los siglos XVI y xviII. Mi experiencia en Ávila me hizo comprender que el estudio de la mitología es una guía de valores, refleja un primer bosquejo de las imágenes de la ciudad, es un intento de señalar los momentos álgidos de la misma, sus preocupaciones más relevantes en determinadas épocas y en definitiva evoca los períodos clave de la historia de la ciudad. En Évora se destaca, de su larga historia, su fundación, la época romana, la Évora cristiana y la Reconquista. Apenas se alude a los varios siglos de dominio musulmán. ¿Por qué esta elección de unas épocas y no de otras? La elección sugiere definiciones de lo que es la historia local, su selectiva naturaleza y su carácter simbólico. La elección es en sí misma significativa. Las dos ciudades, en su mitología, muestran interesantes coincidencias. Tras un pasado romano, más evidente en Évora que en Ávila, fueron reconquistadas más o menos en la misma época a los moros. El fuero de Ávila es conocido por el de Évora, que fue una 
copia del primero. Sus respectivos patronos, San Segundo y San Mancio, primeros obispos contemporáneos de Cristo, fueron en ambos casos inventados en el siglo XVI y en ambos casos Felipe II, en expresión de su poder, obtuvo un hueso de ambos santos. Otros tres santos, Vicente, Sabina y Cristeta, nacidos en Évora, sufrieron martirio en Ávila y allí tienen un magnífico templo a ellos dedicado, aunque les disputa su lugar de nacimiento otra ciudad española, Talavera, una disputa que viene a ser un símbolo de las conflictivas relaciones entre portugueses y españoles. La mitología permite asomarse a la historia y sus valores de una determinada manera. Y es fundamentalmente ideología.

El principal problema de la diacronía es que, por definición, siempre implica un proceso de selección discontinuo, incompleto y parcial. Todas las culturas han hecho su propia selección de su historia. Cualquier división en periodos y épocas es artificial e implica una significación; es una estructura cultural, un discurso a analizar. Como en todo discurso, se ensalzan ciertos valores y se reprimen o suprimen otros. Así, las ciudades se presentan al exterior mediante imágenes cristalizadas en determinadas épocas por ciertas clases, construcciones interesadas hechas de ideas y de símbolos que muestran cómo se piensa a sí misma la ciudad y cómo quiere que se la considere. Esta construcción tiene trascendencia para el futuro de la ciudad, porque los símbolos pueden cambiar nuestro sentido de la orientación. La invocación ritual del pasado provoca la construcción del presente y de un porvenir reivindicados o deseados. Nos enfrenta, en definitiva, con el problema del poder en la elaboración del conocimiento y de la memoria.

Este interés por la mitología de las ciudades me ha hecho volver la vista a ciertos materiales poco utilizados a la vez por historiadores y antropólogos; por ejemplo, a la corografía. Recientemente Richard Kagan ha escrito sobre este tema (1995), un trabajo que paso a resumir aquí. La corografía es un género que surge en la Castilla del siglo xvi y que contiene una teoría sobre la representación de la ciudad. Es la expresión cultural de los pueblos, un lenguaje que les permite desarrollar a través del tiempo su propio sentido de identidad. En el Siglo de Oro, la corografía es sinónimo de las historias de ciudades, las conocidas "Antigüedades y grandezas", mezcla de descripción topográfica y narrativa histórica. Alcanza su mayor éxito en ciudades y municipios que utilizan el género para mostrar al mundo sus logros; cada ciudad había de ser autosuficiente, populosa y próspera, devota en extremo, llena de edificios singulares y gente noble. Las corografías estaban al servicio de intereses políticos de los bandos urbanos. En la narrativa se incorporaban historias para demostrar la antigüedad del municipio, su resistencia a la invasión de los musulmanes, gestas de la Reconquista o los servicios prestados a los reyes. No eran, pues, historias objetivas o desinteresadas, sino que pro- 
porcionaban una visión del pasado que servía a los intereses colectivos de la ciudad o de sus grupos dominantes. El trabajo del comunero Gonzalo de Ayora en 1519 sobre Ávila es la primera corografía que une el elemento descriptivo al histórico, escrita en castellano y con una interpretación de la Edad Media: un catálogo de los servicios prestados por los abulenses a la Corona y de las mercedes que los reyes les habían concedido. Es una interpretación de la historia de Castilla como una reciprocidad entre Corona y Ciudad, no sólo una recopilación de gestas de los reyes como en las crónicas oficiales.

Las corografías comienzan con una descripción geográfica paradisíaca, seguida de la etimología del nombre de la ciudad, la especificación de sus remotos orígenes - símbolo de su nobleza- y reyes míticos (Tubal, Hércules...). Normalmente se señala con minuciosidad el carácter de municipio romano de la ciudad y su conversión al cristianismo. A fines del siglo XVI, Román de la Higuera compuso sus falsos cronicones que los eruditos municipales acogieron con entusiasmo, puesto que establecieron textualmente la llegada de Santiago al municipio, así como los nombres de sus primeros obispos, mártires y santos. Toda la sociedad, desde los eruditos de los pueblos a Felipe II, tenía un interés profundo por establecer su antigüedad cristiana. No debía de ser ajena a este interés la preocupación por la "limpieza" de sangre y el escrutinio de un inmaculado origen de las personas como cristianos viejos. Por ello se pinta una ciudad más bien uniforme en su composición social. Había muy poco interés por las minorías y por ciertos periodos históricos, como los del dominio musulmán. En ocasiones, estos periodos de varios siglos desaparecen y sólo se destaca la Reconquista de un modo épico. Además, se intenta evocar un modelo de la ciudad que la presentara como vasallo fiel, leal a los reyes. A este respecto, se borra o evita cualquier referencia al movimiento de las Comunidades (1520-1521) y se atribuyen los hechos conflictivos a los extranjeros o a la plebe. El modelo, que dura hasta el siglo XVIII, tiene mucha importancia para las oligarquías urbanas y sirve para fortalecer identidades locales y proteger a la ciudad de las reclamaciones de grandeza de otras ciudades; también es una defensa de la independencia e identidad legal frente a la monarquía, por su énfasis en fueros, leyes e instituciones.

Sus autores son eruditos locales que han cogido la pluma por "amor de patria" o para "conservar la memoria" de hechos ilustres, aunque asimismo por otras razones más políticas: como mostrar que la ciudad merece un obispado o voto en Cortes. En ocasiones, son clérigos que pretenden presentar a su ciudad como una Civitas Dei, una comunidad cristiana, y por ello se concentran en descripciones de ermitas y santuarios, mártires y obispos. Inventan para defender el honor de la ciudad o asegurarle un papel en la historia. Se trata de defender, glorificar, celebrar...; las corografías son obras 
patrióticas, aunque en ocasiones las alabanzas se dirigen a quien paga la edición y su "ilustre" genealogía. Estas ediciones tienen poca tirada y van dirigidas al mercado local: a lo sumo unos 500 ejemplares, que se reparten entre cabildos, regidores y personas ilustres, prohombres locales que se identifican con la civitas retratada.

La corografía bien puede ser considerada como un antecedente arqueológico de las monografías modernas de los antropólogos, con las que comparte aspectos positivos y negativos. Entre los primeros está la perspectiva utilizada: la descripción minuciosa sobre el terreno de las características locales, una interpretación de la historia del municipio y la especificación de valores, símbolos y aspiraciones. Entre los negativos, el modelo de ciudad aislada y única que resulta (modelo tan familiar en nuestros clásicos estudios de comunidad...), la descripción interesada (¿cuál no lo es?) y la concentración en un segmento mientras se hacen invisibles otros. En cualquier caso, la corografía es un discurso que hay que analizar, un pedazo de historia mítica que ofrece información sobre lo que es la ciudad y cómo quiere ser considerada, una interpretación desde dentro de la cultura en cuestión. Una se extraña de la poca atención dada a estos documentos, quizá porque están publicados y quizá también porque se supone que simplemente reflejan una colección de patrañas. La idea de "autenticidad" está más extendida de lo que suponemos y parte de una extensa tradición: la que conecta los falsos cronicones en el pasado con la invención de la tradición en el presente. El problema fundamental es: hay algo en la sociedad y la cultura que no sea inventado?

\section{PRESENTE y PASADO EN LA SANTA ÁvILA}

Voy a referirme a continuación a un culto de la ciudad de Ávila, porque ilumina algunos de los problemas que acabo de perfilar ${ }^{4}$. En la llamada "ciudad de los santos", la imagen más venerada no es, como se pudiera imaginar, una santa, la santa por excelencia, Teresa, sino una Virgen, la Virgen de Sonsoles, una imagen que ni siquiera está en la ciudad: es la de una Virgen campesina o, mejor, el lazo que une la tierra ${ }^{5}$ y Ávila, el campo y la ciudad, el pasado y el presente.

El Santuario de Sonsoles se encuentra a unos $5 \mathrm{kms}$. al sudeste de Ávila, en un montecillo que se llama significativamente "Serranillos", un nombre con

\footnotetext{
${ }^{4}$ Este material ha sido tratado más extensamente después de la inicial redacción de estas líneas (Cátedra 2001b).

"Se usa el término "tierra" (en cursiva) en la acepción de territorio independiente y/o administrado por la ciudad, algo así como la actual provincia.
} 
fuertes resonancias campesinas. En este valle han vivido los agricultores y ganaderos que surtían a la ciudad con sus productos. La imagen se asocia con los momentos importantes de la historia de la ciudad. En primer lugar, se la supone traída por un discípulo de los apóstoles, san Segundo, el supuesto primer obispo de Ávila en el siglo I, aunque también se la relaciona con la reconquista de la ciudad a los moros. La primera historia extensa de la Virgen aparece en manuscrito en el siglo XVII, elaborada por un clérigo, B. Fernández Valencia (1686), autor asimismo de varias historias sacras de la ciudad $^{6}$.

En 1480, la primitiva ermita está casi derruida ${ }^{7}$. Ese año, el herrador Andrés Díaz, de la ciudad de Ávila, se dirige al obispado solicitando permiso para restaurarla junto con otras personas. Consiguen 50.000 maravedíes de limosnas en la ciudad y los pueblos de alrededor y, con ellos, los propios cofrades levantan las paredes laterales de la iglesia. Hacia 1500, se ha organizado la Hermandad y reconstruido la ermita.

Una buena manera de acceder al significado de la Hermandad en sus primeras andaduras es a través de sus Ordenanzas, las reglas que los hermanos se daban a sí mismos y que recogen sus inquietudes y necesidades. Sus fines principales son la compañía en la muerte, comensalidad de los vivos y cuidado y control de bienes comunes. Pero, además, este documento ofrece multitud de prescripciones, formas de comportamiento, deberes y derechos. Las ofrendas en especie (animales y grano) fueron muy frecuentes y se subastaban públicamente. Las periódicas comidas y libaciones se convertirán en un motivo constante de crítica por parte de los eclesiásticos. Un tema importante es la composición social de la Cofradía. Al comienzo, todos sus miembros son iguales y de origen modesto, pero con el tiempo la oligarquía urbana terminará haciéndose con el control de la institución. La inicial invitación amable y deferente a los cavalleros de pertenecer a la Hermandad en 1526 ya es un derecho en 1600 y, para entonces, estas personas controlan al menos la mitad de la directiva. Pero este cambio no se produjo de un modo suave y ordenado; por el contrario, parece haber evidencia de tensio-

\footnotetext{
${ }^{6}$ Fernández Valencia, sin embargo, alude a una monografía anterior, la de Luis Pacheco, Tratado de la antigüedad y cosas memorables del Santuario de Sonsoles por mandado y acuerdo de sus patronos, de 1612. También a otra posterior, del Licenciado Diego de Salinas, de 1666.

7 Libro de la Administración de la Hermandad con la bistoria de la invención y desarrollo de la ermita desde sus comienzos, 1578-1622, Fol. 1v, según se lee en Heras Fernández (1998: 20 y 24). Nótese que la historia del herrero aparece escrita casi un siglo después de producirse. Véase también el folleto Decretos para una sentencia (Patronato de $\mathrm{N}^{\mathrm{a}} \mathrm{S}^{\mathbf{a}}$ de Sonsoles 1989: 26).
} 
nes y enfrentamientos serios entre los cofrades caballeros y los del común, tal como aparece en un pleito de $1584^{8}$.

El año en que se datan las Ordenanzas, 1526, coincide con la promulgación de la Bula de Clemente VII, un importante documento en la vida de la Hermandad. Esta Bula ha sido llamada "protectora", defensora de los derechos de la Hermandad frente a diversas instancias eclesiásticas: curas, frailes, párrocos y obispos que en diferentes momentos han tratado de apropiarse de los bienes de la institución. Tras estas tensiones se encuentra el hecho de que la cofradía sea la más rica de Ávila. Especialmente a mediados del siglo XVIII, cuenta con enormes ingresos que invierte en nuevas propiedades y en obras y reformas de los recintos del santuario (Sabe Andreu 2000: 126 ss.). Las antiguas fuentes se refieren a la organización de las procesiones en el pasado y a las fiestas en honor a la Virgen.

Los milagros atribuidos a la Virgen reflejan los míticos orígenes de la ciudad, la Reconquista y la participación de muchos abulenses en afanes guerreros. Con el tiempo, los motivos se vuelven menos traumáticos y más cotidianos, atendiendo a problemas de enfermedad y de sequía. Los labradores traen la Virgen a la ciudad para pedir agua para sus campos. Sobre esto último, una coplilla rezaba así:

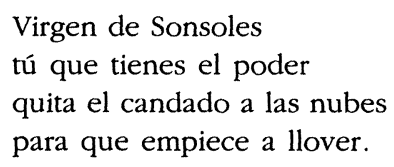

En la actualidad, existe un cuarto enteramente lleno de ofrendas que cada cierto tiempo se van cambiando, especialmente trajes de novia, de la mili, y fotografías de personas que se han curado o han salido ilesas de un accidente. Pero de la mayoría de las ocasiones por las que se la invoca hoy no hay exvotos: ésta es la Virgen a la que acuden ante los exámenes los escolares y los opositores, así como las madres a pedir por la salud de sus hijos.

El material histórico es fundamental para entender el pasado de este culto y su continuidad en el presente. A través de los documentos históricos, corografías y material de archivo, se produce una muy aceptable estampa de la trayectoria de cofradías y hermandades. Algunos clérigos han realizado diversos trabajos y monografías sobre este y otros cultos de la ciudad ${ }^{9}$, que

\footnotetext{
${ }^{8}$ Es un pleito seguido entre Agustín de la Serna, Lorenzo Daza y otros caballeros con el mercader Juan de Coynbra y Antonio Gómez (Archivo Diocesano de Ávila, Sección Pleitos, 1584, libro XXXIV [54/7/4] leg. 34, doc. 4). Debo la referencia a Serafín de Tapia.

9 Por ejemplo, en el pasado López González (1930), un trabajo reeditado varias veces, y recientemente Heras Fernández (1998).
} 
proporcionan una especie de mosaico ideológico del pasado. El siglo XV y especialmente el xvi, la época de su mayor esplendor, ha sido exhaustivamente descrito y analizado desde muy distintas perspectivas.

Un libro recién publicado, Las cofradias de Ávila en la Edad Moderna, de Ana María Sabe Andreu, dedica una especial atención a las cincuenta cofradías abulenses en esa época. Es un ingente y meritorio trabajo. La autora habla de ellas teniendo en cuenta su origen, organización y gobierno, los hermanos, la vida cofradiera, la evolución de la hermandad, las fiestas y la vida económica. A veces se refiere a las relaciones de la cofradía con el exterior y, en su caso, la evolución o extinción de la cofradía. Muy posmodernista, Sabe Andreu indica en el prólogo que:

la realidad histórica ya no existe, por lo que no puede ser estudiada con plena objetividad. El historiador imprime en su interpretación de los hechos pasados sus propias estructuras mentales, resalta unos acontecimientos por encima de otros de manera totalmente subjetiva y personal, como no podía ser menos.

La autora acota el tema cronológicamente desde el siglo xv a 1800. Pese a su declaración de intenciones, esta obra, más que una interpretación, es fundamentalmente un trabajo de catalogación y resumen de la información dispersa que hay por diversos archivos sobre cofradías abulenses de la época moderna. Según ella, fue en los archivos de las cofradías vivas donde (y cito literalmente su plural mayestático):

hemos encontrado y vivido los mejores momentos de este trabajo. El contacto personal con estos cofrades, descendientes y herederos de los hombres y mujeres cuyo pasado estábamos intentando escudriñar, ha sido sin duda lo más emocionante y auténtico de este estudio. Las cofradías se presentaban aquí a nuestros ojos como seres vivos, supervivientes de la noche de la historia... (Sabe Andreu 2000: 14).

Del mismo modo termina su trabajo indicando:

Para terminar no queremos dejar de expresar la emoción sentida al constatar la pervivencia de gran parte de los aspectos arriba indicados. Las cofradías actuales, herederas y continuadoras de cofradías históricas, están compuestas hoy por hombres y mujeres cuyos sentimientos e ilusiones son enormemente parecidos a los de sus antecesores (ibid:: 335).

Y, sin embargo, la autora se queda estrictamente en el año 1800, ni uno más, ni uno menos. Sus comentarios tan sentidos expresan una secreta aspiración a tratar de romper esos límites cronológicos estancos y saltar más allá del peso - excesivo, en mi opinión - del documento de archivo. Como indicara Clifford Geertz en una ocasión (1973: 5-16), lo importante no son los datos (con toda su importancia) sino lo que uno hace con ellos. En el caso 
de Sonsoles, hay un conjunto de temas que no surgen en las fuentes y que, según mi parecer, son fundamentales para entender este culto. Voy a señalar brevemente algunos de ellos.

La Virgen de Sonsoles, patrona de Ávila y de su tierra, muestra una particular competencia con la patrona de la ciudad, santa Teresa. Cuando se alude a cualquiera de las dos imágenes, se refiere también a la otra. La Santa aparece como una figura universal frente a Sonsoles, que representa un culto local. La diferencia fundamental entre ambas radica en la naturaleza eminentemente humana de Teresa y la cuasi divina de Sonsoles. La Santa es más una abulense que otra cosa, más una hermana, una vecina ciudadana; mientras que Sonsoles es la madre que cuida de sus hijos enfermos y se preocupa de los exámenes de los pequeños. Eso explica su especialización actual. La Santa se opone a la Virgen porque se dice que fue "Santa pero no Virgen" (en el sentido de Madre de Dios), lo cual se transforma frecuentemente en "santa pero no virgen" (en su acepción fisiológica). Para algunas personas (algunas muy devotas), la Santa fue un poco casquivana tanto antes de entrar en el convento como, incluso, después; los santos tienen también sus debilidades humanas. La competencia entre ambas figuras es consciente entre la gente y ha llevado a que algunos se pregunten por qué se pone uno u otro nombre a las abulenses. Los dos nombres, Teresa y Sonsoles, son muy frecuentes en la ciudad.

Algunas creencias relacionadas con la imagen de Sonsoles expresan la rivalidad por territorios y competencias divinas. Existen dos imágenes de la Virgen de Sonsoles en el Santuario, la "Grande" y la "Chica". La primera es la imagen principal, la que está en el altar mayor; la más pequeña, la "Chica", está semi-oculta en la sacristía. El hecho de que haya dos imágenes, una pública y otra en cierto modo privada, se corresponde con un comportamiento muy distinto: mientras la "Grande" es la imagen que sale en procesión y la que va a la ciudad en las rogativas, a la pequeña no se la puede mover con tanta facilidad de la ermita. Según me han asegurado gente de todo tipo y condición, la "Chica" no quiere entrar en la ciudad y, pese a su pequeño tamaño, se hace tan pesada que no hay quien pueda traspasar con ella los límites de Ávila. La gente asegura que si se la traslada en un carro, éste se romperá; y si la lleva la gente justo en el cruce con el puente del SanctiSpiritus - una de las antiguas entradas a la ciudad-, su enorme peso impedirá el movimiento a los porteadores. La Virgen, pues, al llegar al territorio de la ciudad, no quiere entrar en ella. La razón de su negativa a cruzar los límites de la ciudad me la insinuaron varias veces con comentarios del tipo de: "Como han nombrado en Ávila patrona a santa Teresa..., no quiere ir a Ávila" o "La Virgen de Sonsoles está enfadada porque nombraron patrona a santa Teresa y por eso no le gusta ir a Ávila". Es decir, Sonsoles y 
Teresa tienen cada una su propia jurisdicción y distintas reglas en distintos espacios.

La devoción a Sonsoles se debe fundamentalmente, hoy como ayer, a su fama de milagrosa. El Santuario es hoy muy visitado cuando viene el buen tiempo. Para la gente de la ciudad, el trayecto a pie a Sonsoles se ha convertido en una caminata que unos hacen por devoción - por ejemplo, los que acuden a la Misa del Peregrino- y otros por hacer ejercicio. Humorísticamente, hay quien llama a Sonsoles "la Virgen del Colesterol". Sonsoles se asocia al verano, época en que Ávila empieza a salir de su letargo invernal. Hoy, para los vecinos de Ávila, el culto a esta imagen campesina tiene cierto sentido deportivo, pues además de la devoción y el sacrificio, la asistencia a la misa de los domingos concentra a muchos - especialmente hombres- que realizan el trayecto a pie y con calzado cómodo.

En cambio, para la gente del campo, Sonsoles tiene una utilidad muy básica y práctica para sus necesidades agrícolas. La Virgen trae el agua si se la lleva a la ciudad y se le hace una novena. Resulta una paradoja que cuando los labradores necesitan agua para sus campos, traigan una imagen campesina a la ciudad. A la Virgen - se dice- se la traslada para que "vea" lo secos que están los campos y los bendiga. El traslado de la Virgen forma parte de un elaborado ritual y su trayecto sigue una ruta fija. Las autoridades civiles y eclesiásticas se hacen cargo de la imagen de un modo muy formal y ofrecen a cambio un presente en cera. La Virgen ocupará el mayor templo de Ávila, la catedral, auxiliada por su santero. Se la devuelve a su ermita campesina de la misma manera.

Una oposición fundamental en torno a la dicotomía campo-ciudad aparece en el contexto de las fiestas en honor a la imagen. Las fiestas se dividen en dos grupos claramente delimitados: por un lado, la fiesta ciudadana del Patronato, que tiene lugar en el mes de julio; por otro, las Tres Ofrendas de las cofradías campesinas, que se suceden al acabar las cosechas, en octubre ${ }^{10}$. La fiesta del Patronato se dice que es "señorial". Acuden a ella las autoridades y el Ayuntamiento es invitado formalmente a participar; el primer acto es la ofrenda de un ramo de flores del alcalde a la Virgen. Todas las fiestas incluyen misas, procesiones y subastas, aparte de otros actos ocasionales. Las Ofrendas están organizadas a través de "los escuadras", los representantes de las cofradías en las distintas agrupaciones campesinas que se encargan de las

${ }^{10}$ Estas son las mayores celebraciones: Primer domingo de julio, Fiesta del Patronato. Primer domingo de octubre, Ofrenda Chica, Cofradía de la Sierrecilla. Segundo domingo de octubre, Ofrenda Grande, Cofradía del Valle Amblés. Tercer domingo de octubre, Ofrenda de La Colilla. La Cofradía de la Sierrecilla está compuesta por catorce pueblos, la del Valle Amblés por otros catorce y la de La Colilla por un solo pueblo. 
celebraciones, al mando de los cuales hay un "escuadra mayor", que es un cargo anual por turno entre los distintos pueblos. Los escuadras despliegan sus banderas ante la Virgen con gran vistosidad. La cofradía más importante, por la vitalidad de sus pueblos y nivel de participación, es la del Valle de Amblés, que se encarga de la Ofrenda Grande, en el segundo domingo de octubre. Si la fiesta del Patronato es, como se dice repetidamente, la "más señorial", oficial y ciudadana, la de la Ofrenda Grande es la de mayores dimensiones, popular y campesina. En las fiestas se subastan diversos productos; los del Patronato suelen ser bienes ciudadanos, mientras que en las Ofrendas hay pequeños animales y productos del campo.

La relación entre la ciudad y el campo y sus respectivas fiestas - los ciudadanos y la fiesta del Patronato, los campesinos y sus Ofrendas- no conforman exactamente una relación de iguales. Los de las cofradías rurales se quejan veladamente del control ciudadano y de su asociación con los más ricos, pese a sus humildes orígenes. Aunque se dice que cualquiera puede pertenecer al Patronato, no todos opinan así, ya que hay quien considera que todavía es una hermandad elitista; no obstante, como indican los abulenses, "ya no es lo que era". El Patronato de Sonsoles tiene cierto peso social; es una de esas asociaciones claves para la relación con el "Ávila" significativa. Sin embargo, pese a este control, también se afirma que las cofradías rurales son precisamente las que proporcionan la grandeza de Sonsoles y la mayor parte de sus riquezas.

Pero, en los últimos años, la mayor oposición se ha producido entre los miembros del Patronato y el obispo de Ávila. En febrero de 1988, asistí a la Asamblea General de Sonsoles en un día frío y desapacible, cubierto de nieve. La asistencia a la reunión fue por eso especialmente escasa; no llegó a la veintena del total de los 1.855 hermanos del momento. Comenzó rezándose un Avemaría, como sucede en casi todas estas reuniones y, entre otros asuntos, se trató de la construcción de un bar restaurante en los terrenos del Santuario y la adjudicación de las obras a un constructor y hermano cofrade. Tras varias cuestiones e informaciones, por último se dio cuenta de gastos e ingresos. Lo más llamativo de la asamblea giró en torno al pleito que el Patronato tenía con el obispo de la ciudad. El presidente en ese momento era un sacerdote y se refirió con calor y admiración a las hermandades y cofradías, organizaciones de laicos que habían logrado valientemente resistir hasta cinco siglos en algunos casos. Hubo por parte de todos bastantes críticas al obispo. Ni que decir tiene que quedé bastante sorprendida por estos comentarios en la católica Ávila.

Este conflicto reciente se gestó en los años ochenta. El Patronato ha editado un folleto, ya citado (Patronato 1989), en que se narra el proceso seguido entre ambas partes. Básicamente sucedió así: en 1981, el obispo de 
Ávila emite un decreto estableciendo la separación de los bienes y de las administraciones del Santuario y del Patronato, y nombrando por su cuenta un nuevo Rector del Santuario. El Patronato impugna el decreto, aludiendo a la bula pontificia de Clemente VII de 1526, y acude a diversos tribunales civiles y eclesiásticos españoles, así como a la Congregación Romana del Clero. Tras varios avatares, la Plenaria de Cardenales del Supremo pronunciaba la sentencia definitiva el 15 de abril de 1989 dando la razón al Patronato. En el citado escrito del Patronato se hace un pequeño repaso histórico de la creación y desarrollo de la Hermandad, narra los tempranos intentos de párrocos y frailes por hacerse con el control del Santuario y los derechos y deberes concedidos mediante la Bula.

En definitiva, este conflicto era una lucha de intereses entre obispo y Patronato por hacerse con el control de los bienes del Patronato. Las alegaciones del obispo se desprenden del texto: para él se trata de un tema de pastoral y no se puede dejar que un santuario quede en manos de los laicos. A esto se contesta que no es cuestión de pastoral sino de justicia y que no es ninguna garantía que esté en manos de clérigos, tal como indica este expresivo párrafo:

La verdad es que en la diócesis ha habido otros santuarios en manos del clero. Ahora, por las causas que fueren, están convertidos en nidos de aguiluchos, abandonados con sus piedras de sillería esfacelándose y derrumbándose en lluvia de arenilla. Éste, no sólo no está desintegrándose, sino que sus titulares lo han convertido en un santuario mariano, de peregrinación, de adoración, durante siglos... Pensamos que es una institución modélica... (Patronato 1989: 9).

La clave de este proceso aparece en las posibilidades económicas del Patronato, que colabora "en el orden de ayudas vocacionales, de peregrinos, de ayuda a iglesias pobres, restauración de santuarios, edición y propagación de catecismos, etc.". No obstante, hay que decir que no es exactamente un enfrentamiento entre obispo y Patronato cuanto una oposición entre dos líneas eclesiásticas. Poco después del fallo a favor del Patronato, murió su Presidente, un sacerdote al que se le dedica la frase: "artífice del gran triunfador del pleito que [en] el siglo xx mantuvo el Patronato" ${ }^{11}$. Por su parte, el obispo fue trasladado de sede poco después del fallo definitivo. Hay quien asegura que Sonsoles le costó su puesto al obispo.

El pleito ha sido muy comentado en Ávila. Las noticias del mismo y las distintas etapas del proceso han ocupado páginas de la prensa local, conversaciones privadas y públicas e incluso parte de los sermones de algunos púlpitos. En su mayor parte, la gente de Ávila tomó partido por el Patronato

${ }^{11}$ Ángel Córcoles Bordera en El Diario de Ávila, 24 de marzo de 1991. 
y se hizo en buena medida experta en historia, derecho eclesiástico y bulas. Mis conversaciones con los hermanos enfatizaban la existencia del santuario gracias a la generosidad del humilde herrero y un grupo de hermanos que lo reconstruyeron en el pasado. También se refieren repetidamente al hospital de peregrinos que sostenía la hermandad antiguamente y a las caridades que hoy mantiene. Los motivos principales del conflicto pueden reducirse a dos: su independencia y sus medios económicos que quedan resumidos en la frase siguiente: "...el clero lo quiere [el control] porque es muy rica ella [Sonsoles]... como siempre ha sido independiente de todas las iglesias".

Sonsoles es un símbolo importante de identidad en Ávila. Parece irónico que la Virgen más significativa de la ciudad, el culto más extendido y enraizado, sea una imagen campesina y una imagen casi desconocida para el que no es de Ávila. La asociación que normalmente se ha realizado de Ávila con santa Teresa corresponde a un problema de contexto: la Santa es la hija, o la hermana más conocida, la vecina ilustre, la embajadora ante el mundo. La Santa, además, se asocia a los Cuatro Postes y al centro de la ciudad, pero especialmente al norte, donde está el Monasterio de la Encarnación, la parte más fría, más ascética de la ciudad. Sonsoles, por su parte, es la madre que vela por sus hijos y que protege la tierra, responsable de su fecundidad; por ello, no es extraño que se encuentre al sur, en la zona más soleada y amable de la tierra, la zona agricultora por excelencia. Las dos figuras son complementarias, pese a los celos divinos y a los recelos humanos. Los celos entre Teresa y Sonsoles muestran las jerarquías divinas y sus respectivas jurisdicciones y competencias. Muestran también cuán humanos son los sentimientos y comportamientos de las figuras divinas.

Sonsoles es la imagen de la nueva sociedad y de la antigua. La historia de la Hermandad refleja los esfuerzos de los abulenses por organizarse alrededor de un culto. Sus Ordenanzas muestran la importancia de la cultura y los valores sociales que contienen estas instituciones. Son a la vez un instrumento para que los tratos sean más fiables, una forma de suavizar la agresividad entre los hombres, tribunales populares para dirimir diferencias, manual de buenas maneras y reglas de comportamiento. Se trata, en suma, de que las relaciones humanas y divinas sean más armónicas y menos conflictivas. Aunque su función principal se dirija hacia la enfermedad y la muerte, proporcionando al que se va oraciones, compañía, asistencia y recuerdo, sin embargo también muestran, a través de sus fiestas, comidas y libaciones, las necesidades de los vivos, cierta alegría de vivir y quizá también un hambre endémica que se palía con estas celebraciones. A juzgar por el éxito de la cofradía, parece que la unión beneficia a todos. Esto se consigue a través del cuidadoso examen de las cuentas, la compleja fiscalización y cuidado de los bienes comunes, el control exhaustivo de rentas y propiedades. El que 
estas instituciones hayan durado siglos es la mejor prueba de su idoneidad; muy frecuentemente, una buena manera de proteger bienes comunes de la voracidad de las instancias eclesiásticas.

Estos enfrentamientos entre laicos y eclesiásticos son evidentes a lo largo de la historia de Sonsoles. Algunos comentarios en las Ordenanzas sugieren las críticas de curas y frailes a los supuestos "excesos" que, hoy como ayer, tienen que ver con la comensalidad. En 1526, los hermanos se resienten de ser considerados "comedores o bebedores"; en 1981, la construcción de un bar restaurante en terrenos del Santuario es la espita del enfrentamiento con el obispo. Las proclamaciones de pureza religiosa del clero son, pues, aspiraciones ya antiguas: ese intento por separar las cuestiones sagradas de las profanas (¡cómo si eso fuera posible...!), por distinguir tajantemente entre comunión y comensalidad. Detrás de tales prescripciones y enfrentamientos antiguos y modernos está el intento de control por parte del estamento eclesiástico de las organizaciones laicas y las subsiguientes declaraciones de independencia y autonomía de esos obstinados hermanos. Y fundamentalmente de lo que se trata es del control económico de estas instituciones. La Bula de 1526 es necesariamente "protectora". Lo que está en juego son las abundantes limosnas que se recogen en el Santuario y el uso que se hace de ellas, el destino de excedentes y caridades.

Sin embargo, no se puede pensar en una nítida oposición entre un conjunto de pobres hermanos y un grupo de codiciosos clérigos. Ni todos los hermanos son pobres ni los clérigos forman un bloque. Desde muy temprano, los patrones de Sonsoles dejan de ser pobres. Ya en 1625 se trata de limitar a 50 el número de sus patronos; en la actualidad, todavía hay eco de esa vieja pertenencia de clase. Por otra parte, también hay clérigos, capellanes y abogados eclesiásticos dentro del propio Patronato, tanto al solicitar la Bula al Papa como en el litigio con el obispo. La norma actual, que alterna como presidente y vicepresidente un laico y un sacerdote, plasma con rotundidad la mezcla de los dos estamentos.

Pero quizá la mayor oposición no se produce dentro de distintos colectivos de la ciudad sino entre ésta y su tierra o, en términos del culto a Sonsoles, entre el señorial y ciudadano Patronato y las más modestas cofradías rurales. Sonsoles ofrece una perspectiva simbólica de las jerárquicas relaciones entre el campo y la ciudad, de la dependencia que el campo y los campesinos tienen de la ciudad. Pero quizá, después de todo y pese a su sentido jerárquico, a través de Sonsoles se reconoce también, de un modo simbólico, la dependencia en sentido opuesto, la que tiene la ciudad de su ruralía, el reconocimiento de su intrínseca naturaleza rural o de que un día fue rural. $\mathrm{O}$ quizá su complementariedad. El Mercado Chico, la Plaza Mayor que alberga al Ayuntamiento, se llena cada viernes de igual modo con un mercado de 
frutas y verduras que venden directamente los campesinos. La Virgen campesina recorre la ciudad cuando se precisa de ella y se recoge en la catedral. Los campesinos tienen que venir a vender sus productos a la ciudad, pero ésta también precisa de ellos para su supervivencia. El poder está en la ciudad, en el Ayuntamiento y la catedral; ésta es la expresión de la cultura, de la organización social. Pero Sonsoles es también, como las frutas y verduras, un "producto" campesino, la expresión del poder de la naturaleza.

Sonsoles logra unir hábitats muy distintos: la ciudad, el valle y la montaña o incluso un pequeño pueblo. En torno a esta imagen se logra una confederación de comunidades unidas a través de las Ofrendas, que luchan por su continuidad. Nótese que estos grupos de pueblos están juntos, pero no mezclados, y que cada una de las entidades tiene su propia fiesta, conserva sus propias características y especificidad. El juego de la bandera por parte de las cofradías rurales es una afirmación simbólica de su identidad, no en vano lo juegan los escuadras, los representantes de los pueblos de la sierra y el valle. Las ofrendas en especie son también signos de sus productos y modos de vida.

Los nuevos usos del campo y la ruralía están hoy en contradicción. La imagen de Sonsoles proporciona a la ciudad un lenguaje para expresar a la vez su despegue del campo y la vuelta al campo. Los nuevos usos de Sonsoles, su vitalidad, la continua afluencia de fieles, están asociados a una nueva significación de lo urbano y rural, una deliberada búsqueda de lo rural en lo urbano, el proceso de urbanización del campo, una mayor movilidad. Los campesinos llevan años emigrando a la ciudad, algunos por trabajo, otros para pasar lo más difícil de los crudos inviernos en las más confortables viviendas ciudadanas. Al mismo tiempo, los ciudadanos han recorrido el camino inverso al habilitar viejas construcciones rurales para sus viviendas permanentes o de fin de semana. La Virgen de Sonsoles ejemplifica a tantas madres rurales que han visto a sus hijos tener que abandonar la tierra pero que vuelven finalmente a ella. La situación del Santuario en el campo enseña a los ciudadanos la necesidad de ir "más allá" de la ciudad, traspasar las murallas, unirse a la naturaleza, reconocer la interconexión de Ávila y su tierra. E incluso la irónica etiqueta de la "Virgen del Colesterol" parece indicar que no hay salud sin el respeto por la naturaleza.

El protagonismo masculino antiguo y moderno en la directiva del Santuario y la casi exclusiva frecuencia de asistencia masculina a Sonsoles en la Misa del Peregrino, a pesar de la usual asociación de la iglesia con la mujer, quizá estén reproduciendo el antiguo modelo de relación de la ciudad con el exterior. El hombre salía fuera de los límites de la ciudad a conquistar, mientras la mujer se quedaba murallas adentro. En cierto modo el Santuario sigue apegado a la tradición, pero también se adapta a nuevas formas de sociabi- 
lidad, refleja los cambios en el modo de vida, ensaya nuevas formas de definirse en la ciudad. Las peregrinaciones a Sonsoles y la celebración de esta imagen no sólo producen movimiento de gente, grupos y comunidades, sino principalmente significados, poderes, ideales, debilidades y mundos en conflicto. Se trata de descubrir contenidos llenos de significado para el presente, y cambios de lugar llenos de sentido a través de la invocación ritual del pasado.

Estas líneas intentan sugerir la enorme complejidad que supone el estudio de cualquier aspecto cultural. Una institución que ha durado quinientos años no puede obviar el escrutinio de su historia. Sin embargo, la lectura histórica clásica es una lectura parcial; hay un conjunto de temas que no surgen en las fuentes: aspectos significativos y vitales que están ahí fuera. Ana María Sabe Andreu, desde su parcela y época particular al estudiar las cofradías, ha intuido la enorme riqueza que supone la cultura en movimiento, los seres humanos que están haciendo historia. Como Greg Dening ha indicado (1998), la historia es "una metáfora del pasado y una metonimia del presente".

\section{PENSAR CON LA HISTORIA}

Termino con una referencia concreta a Carl E. Schorske, un historiador americano de origen austríaco a quien se debe el reciente libro Pensar con la bistoria (2001), que recoge algunos ensayos suyos hace tiempo publicados. Schorske es un autor muy estimulante de diversos trabajos sobre ciudades europeas, Budapest o Viena por ejemplo. Para él, pensar con la historia no es lo mismo que pensar sobre la historia como método general de construcción de significado. Pensar con la historia supone la utilización del material del pasado, así como de las configuraciones en las que lo organizamos y comprendemos, para orientarnos en el presente en que vivimos. Pensamos con las imágenes que nos formamos del pasado a fin de definirnos a nosotros mismos a través de la semejanza o la diferencia.

En este libro reciente estudia cómo en el siglo xx se aprendió a pensar sin la historia, a diferencia de la Europa del XIX en que la historia se convirtió en una forma privilegiada de construcción de significado para las clases ilustradas (pintura, novela histórica, historia del arte, literatura); la época en que la modernización de la economía y la industrialización, así como el nacionalismo, provocaron la búsqueda de vínculos con el pasado. Las ciudades también se apropiaron de estilos de tiempos pasados. Al final de siglo, esta práctica cultural se abandonó a favor de una modernidad ahistórica; la ciencia, la arquitectura, la pintura o la música moderna no tienen en cuenta la historia concebida como tradición. Pero en ambos casos se trata de un intento de dominar la modernidad, con o sin la historia; de un mismo intento de 
dar forma y significado a la civilización europea. El posmodernismo significa una vuelta a la historia como un proceso continuo.

En el último capítulo del libro, titulado "La historia y el estudio de la cultura", Schorske señala que la historia cuenta con una musa, Clío, gracias a los intelectuales de Alejandría que la asignaron a este oficio. Como mujer en un mundo de hombres, la historia ha sido siempre dependiente, compañera, enriqueciendo los resultados de otros. Indica cómo Clío tiene obsesión por las fechas; el calendario es para ella una especie de libro sagrado. Pero está mal preparada para la autonomía: la historia no tiene ni territorio ni principios propios. Describe sus objetos tremendamente diversos bajo el aspecto del cambio, bajo el mandato del tiempo. Clío, dicho brevemente, está al lado de la rueca; hace girar el hilo en parte a partir de materiales que ha elegido y cardado, pero que no ha cultivado, y en parte a partir de conceptos que ha adoptado pero que no ha creado. Su habilidad especial consiste en tejerlos en forma de explicación con significado en el telar del tiempo, un telar que verdaderamente es de su propiedad. Esta habilidad hace que otros valoren mucho a Clío... Los rudimentos del oficio de historiador son muy sencillos y sus intereses con respecto a la cultura muy variables e inconstantes, y se renuevan de acuerdo con su propia situación histórica, su cambiante relación con la sociedad y las estructuras y problemas de la misma ${ }^{12}$.

\section{BIBLIOGRAFÍA CITADA}

AMELANG, JAMES. 1986. La formación de una clase dirigente: Barcelona 1490-1714. Barcelona: Ariel.

\footnotetext{
${ }^{12}$ Estoy segura de que estas líneas son polémicas. El desenfado con que algunos antropólogos nos referimos a la historia denota poca familiaridad con las nuevas ideas y corrientes de la historiografía actual. En el otro lado sucede algo similar, como lo muestra el propio Schorske y sus comentarios en relación con la a-historicidad de la antropología, algo que, como he tratado de indicar, pertenece al pasado. Concuerdo con Tapia en que hoy día los historiadores no sólo describen sino que además explican, duplican análisis de estudios históricos (como, por ejemplo, la ingente producción en torno a la Revolución Francesa o la Guerra Civil española) y no sólo estudian el cambio sino la continuidad. Véanse las interesantes propuestas metodológicas de este historiador en relación con la investigación de los moriscos $(1991,1999)$, que son básicas para cualquier investigación social (superación del positivismo, del estudio de un grupo de manera aislada fuera de su contexto, el planteamiento del status de las fuentes utilizadas y la necesidad de utilizar métodos desarrollados por disciplinas cercanas como la antropología social). El autor indica concretamente: “...las fuentes en realidad son una construcción epistemológica del historiador [...]. Somos nosotros, los historiadores, quienes diseñando los objetivos y referencias metodológicas recreamos... inventamos las fuentes de nuestro propio trabajo" (Tapia 1999: 203-204).
} 
Cabezas, Eduardo. 2000. “Los de siempre”. Poder, familia y ciudad (Ávila 1875-1923). Madrid: CIS-Siglo XXI.

CÁTEDRA, MARÍA. 1988. La muerte y otros mundos. Gijón: Júcar.

-. 1989. La vida y el mundo del vaqueiro de alzada. Madrid: CIS-Siglo XXI.

-. 1992. This World, Other Worlds. Traducción de William Christian. Chicago: University of Chicago Press.

- 1997. Un santo para una ciudad. Ensayo de antropología urbana. Barcelona: Ariel.

-. 1999. "El origen de las ciudades: la invención de la tradición en Évora y Ávila", en A. Medeiros (coord.), Actas del VIII Congreso de Antropología 9, Mesa de Trabajo I, Recreaciones Etnográficas: 47-63. Santiago de Compostela: Ediciones de la Universidad.

- 2001a. "Simbolismo en la ciudad. Una comparación de dos ciudades ibéricas", en M. Cátedra (ed.), La mirada cruzada en la Península Ibérica: 273-308. Madrid: Catarata.

-. 2001b. "La ciudad y su tierra: la Virgen de Sonsoles". Revista de Antropología Social 10: 71-121.

CÁtedra, María, y Ricardo SANMARTín. 1979. Vaqueiros y pescadores. Dos modos de vida. Madrid: Akal.

CÁtedra, MARÍA, y SERAFÍn de TAPIA. 1997. "Imágenes mitológicas e históricas del tiempo y el espacio: las murallas de Ávila". Política y Sociedad 25: 151-183.

CHRISTIAN, William. 1997. Las visiones de Ezquioga. La Segunda República y el Reino de Cristo. Barcelona: Ariel.

COFRAdía de Nuestra Señora de Sonsoles. 1526. Libro de las ordenanças de la cofradía de Nuestra Señora de S. Soles llamada de la Buena muerte, bechas y confirmadas con Bula Apostólica, Año del Señor MDXXVI. Manuscrito.

COHN, BERNARD S. 1990. An Antbropologist Among the Historians and Other Essays [19551983]. Nueva Delhi, India: Oxford University Press.

COMAROFF, JEAN. 1985. Body of Power, Spirit of Resistance: The Culture and History of $A$ South African People. Nueva York: Hill and Wang.

COMAROFF, JEAN, y JOHN L. COMAROFF. 1991. Of Revelation and Revolution: Christianity, Colonialism and Consciousness in South Africa. Chicago: University of Chicago Press.

DENING, GREG. 1998. History's Anthropology: The Death of William Gooch. Nueva York: University Press of America.

FRIEDMAN, JONATHAN. 1992. "The Past in the Future: History and the Politics of Identity". American Antbropologist 94 (4): 837-859.

FERnÁNDEZ VAlencia, B. 1686. La Divina Serrana de Sonsoles. Manuscrito. Ávila, Archivo Patronato de Sonsoles.

GEERTZ, ClifFORD. 1973. The Interpretation of Cultures. Nueva York: Basic Books.

HERAS HERNÁNDEZ, FÉLIX DE LAS. 1998. El Santuario de Nuestra Señora de Sonsoles. Ávila: Patronato de Nuestra Señora de Sonsoles.

LÓPEZ GONZÁlez, ViCENTE. 1930. Historia de Nuestra Señora de Sonsoles. Ávila: Patronato de Nuestra Señora de Sonsoles.

LUQUE, ENRIQUE. 1988. "María Cátedra: La muerte y otros mundos". Revista Española de Investigaciones Sociológicas 43: 184-187.

KAGAN, RICHARD. 1995. "La corografía en la Castilla moderna. Género, historia, nación". Stvdia Historica. Historia Moderna XIII: 47-59.

KRECH III, SHEPARD. 1996. "Etnohistory", en D. Levinson y M. Ember (eds.), Encyclopedia of Cultural Antbropology: 422-429. Nueva York: H.Holt \& Co. 
Mitchel, Jon P. 1997. "A Bridge Too Far? The Relationship Between History and Anthropology". Contemporary European History 6: 399-411.

PATRONATO de la ermita y hospital de peregrinos N ${ }^{\mathbf{a}} \mathrm{S}^{\mathrm{a}}$ de Sonsoles. 1989 Decretos para una sentencia 1981-1989. Ávila: Patronato de Nuestra Señora de Sonsoles.

SABE ANDreU, ANA Marf́A. 2000. Las cofradias de Ávila en la Edad Moderna. Ávila: Diputación Provincial de Ávila-IGDDA.

SAHLINS, MARSHALl. 1981. Historical Metaphors and Mythical Realities: Structure in the Early History of the Sandwich Islands Kingdom. Ann Arbor, Michigan: The University of Michigan Press.

- 1983. "Other Times, Other Customs: The Anthropology of History". American Anthropologist 85: 517-544.

-. 1985. Islands of History [1981-1985]. Chicago: The University of Chicago Press.

SCHORSKE, CARL E. 2001. Pensar con la bistoria. Ensayos sobre la transición a la modernidad. Madrid: Taurus.

STURTEVANT, WILliAM C. 1966. "Anthropology, History and Ethnohistory". Ethnobistory 13: 1-51.

TAPIA, SERAFÍN DE. 1991. La comunidad morisca de Ávila. Ávila: Diputación Provincial de Ávila-IGDDA.

- 1999. "Los moriscos de la Corona de Castilla: propuestas metodológicas y temáticas", en Actas del VII Simposio Internacional de Mudejarismo. Teruel: Centro de Estudios Mudéjares.

TAX FreEman, SuSAN. 1979. The Pasiegos Spaniards in No Man's Land. Chicago: The University of Chicago Press. 